\title{
NEUROGENESIS INDUCED BY SEIZURES IN THE DENTATE GYRUS IS NOT RELATED TO MOSSY FIBER SPROUTING BUT IS AGE DEPENDENT IN DEVELOPING RATS
}

\author{
Yaima del Carmen Garrido Sanabria', Gustavo Adolfo Argañaraz', \\ Eliangela Lima', Margareth Rose Priel', Edvaldo da Silva Trindade², \\ Luana Mazzacoratti Loeb', Fulvio Alexandre Scorza', Esper Abrão Cavalheiro', \\ Débora Amado', Maria da Graça Naffah-Mazzacoratti ${ }^{3}$
}

\begin{abstract}
Neurogenesis in the dentate gyrus (DG) has attracted attention since abnormal supragranular mossy fiber sprouting occurs in the same region, in temporal lobe epilepsy. Thus, we submitted developing rats to pilocarpine-induced status epilepticus (SE) to study the relationship between neurogenesis and mossy fiber sprouting. Groups were submitted to SE at: I-P9, II-P7, P8 and P9, III-P17 e IV-P21. Neurogenesis was quantified using BrdU protocol and confirmed through double staining, using neuronal pentraxin. Other animals were monitored by video system until P120 and their brain was studied (Timm and Nissl staining). The neurogenesis at P17 ( $p=0.007)$ and P21 ( $p=0.006)$ were increased. However, only P21 group showed recurrent seizures and the mossy fiber sprouting in the same region, during adult life, while P17 did not. Thus, our results suggest that neurogenesis is not related to mossy fiber sprouting neither to recurrent spontaneous seizures in pilocarpine model
\end{abstract}

KEY WORDS: neurogenesis, epilepsy, development, pilocarpine, BrdU, immunohistochemistry.

\begin{abstract}
A neurogênese induzida por crises no giro denteado não está relacionada ao brotamento de fibras musgosas, mas é dependente da idade, em ratos durante o desenvolvimento

Resumo - A neurogênese no giro dentado tem atraído atenção já que ela ocorre na mesma região do hipocampo que o brotamento das fibras musgosas, na epilepsia do lobo temporal. Assim, submetemos ratos em desenvolvimento ao status epilepticus induzido (SE) por pilocarpine. Grupos foram submetidos em IP9, II-P7, P8, P9; III-P17 e IV-P21. A neurogênese foi observada usando o protocolo do BrdU e confirmada por dupla marcação com pentraxina neuronal. Outros animais foram monitorados até $\mathrm{P} 120$ e seus cérebros analisados (Nissl e Timm). A neurogênese nos grupos P17 ( $p=0,007)$ e P21 ( $p=0,006)$ aumentaram. Entretanto, o P21 apresentou crises espontâneas e brotamento de fibras musgosas, na mesma região onde ocorreu a neurogênese, enquanto o grupo P17 apresentou somente aumento na neurogênese. Assim, nossos resultados sugerem que o fenômeno da neurogênese não está relacionado com o brotamento de fibras musgosas nem com o aparecimento de crises espontâneas e recorrentes no modelo da pilocarpina.
\end{abstract}

PALAVRAS-CHAVE: epilepsia, desenvolvimento, neurogênese, pilocarpina, BrdU.

Postnatal proliferation of the granule cells in the dentate gyrus (DG) has been repeatedly demonstrated in rodent, monkey and human brain ${ }^{1,2}$. As observed, the neurogenesis in the adult hippocampal formation is responsible for a large pool of new granule cells in this region ${ }^{3}$, which could be involved in plastic modification of local circuitry in several physiological or pathological situations. These newborn cells are able to express specific neuron chemi- cal markers ${ }^{4}$. Several experimental evidences have shown that postnatal neurogenesis could be modulated by different physiological and non-physiological conditions $s^{5-7}$ especially after acute seizure episodes, such as electroconvulsive shock ${ }^{8}$ or in chronic epileptic conditions ${ }^{4,9,10}$. Since adult neurogenesis is commonly observed in the dentate gyrus, this enigmatic phenomenon has received close attention due to its possible relationship with the

Escola Paulista de Medicina, Universidade Federal de São Paulo, São Paulo SP, Brasil: 'Disciplina de Neurologia Experimental; ${ }^{2}$ Disciplina de Biologia Molecular, ${ }^{3}$ Disciplina de Bioquímica. FAPESP, CAPES, CNPq, PRONEX and FADA supported this study.

Received 7 July 2008, received in final form 29 September 2008. Accepted 13 October 2008.

Dra. Maria da Graça Naffah Mazzacoratti - Laboratório de Neurologia Experimental / Universidade Federal de São Paulo / Escola Paulista de Medicina Rua Botucatu 862 - 04023-900 São Paulo SP - Brasil. E-mail: naffahmazz.nexp@epm.br 
abnormal supragranular mossy fiber sprouting, which occurs in TLE".

In adult animals, the relationship between mossy fibers sprouting and the occurrence of recurrent spontaneous seizures in temporal lobe epilepsy is controversial. Longo et al. ${ }^{12}$ showed that recurrent seizures are not prevented when mossy fiber sprouting was blocked. This criteria contrast with suggestions of several authors that explain that mossy fibers sprouting and spontaneous seizures are related phenomena in several TLE models ${ }^{11,13}$. Furthermore, the mechanisms mediating neuronal damage and mossy fiber sprouting seem to be age-dependent ${ }^{14-16}$. Previous ontogenetic study, in the pilocarpine model of epilepsy, showed an age-dependent brain damage, related to long-lasting seizures ${ }^{17}$. According to these authors, the chronic phase (spontaneous recurrent limbic seizures) and mossy fibers sprouting occurs if $S E$ is induced after a post natal period of 18 days $(\mathrm{P} 18)^{17}$ as well as in adult rats ${ }^{18}$. Interestingly, animals submitted to $S E$ during three consecutive days, (P7, P8 and-P9) showed an hippocampal electrographic pattern, similar to absence seizures as well as an impairment of behavioral skills (memory and learning disabilities) during adult life ${ }^{19}$.

Thus, the aim of the present study was to investigate the relationship between the neurogenesis and the mossy fiber sprouting, induced by long-lasting seizures in the hippocampus of rats, during different stage of postnatal life and during the early adulthood. The present work also studied the effect of $S E$ intensity in the development of hippocampal neurogenesis.

\section{METHOD}

All experimental protocols were approved by the Ethic Committee of the Federal University of São Paulo (UNIFESP). Wistar rats were housed under environmental controlled conditions (7 am $/ 7$ pm light/dark cycle, 22-24ㅇ) with free access to food and water. Male offspring were housed with their mother until P21. In all experiments, littermates were randomly assigned to experimental or control groups. Ten animals per group were used. The experimental groups used were: I - animals submitted to SE at P9, II - animals submitted to three consecutive SE at P7, P8 and P9, III - animals submitted to SE at P17, IV - animals submitted to SE at P21. The animals from group I and II weighted between 10-12g and 15-18, respectively. Those from the group III and IV weighted between 27-31g and 36-42g, respectively. Each experimental group was compared to its proper control group, generally from the same hatch. The rats of all groups were pre-treated with $0.1 \%$ scopolamine methyl nitrate $(1 \mathrm{mg} /$ $\mathrm{kg}$, s.c.) to prevent peripheral effects of pilocarpine and after 30 min the experimental groups were treated with $4 \%$ pilocarpine hydrochloride using age-dependent doses (Group I and II: 380 mg/kg, Group III: 225 mg/kg and Group IV: 180 mg/kg, i.p.) according to established protocol, described by Priel et al..$^{17}$. The control groups received saline solution $(0.9 \% \mathrm{NaCl})$ instead of pilocarpine. All animals were observed during seizure periods returning to their mother cage at the end of the SE period.

Six animals of all groups were studied to analyze the incorporation of 5-Bromo-2'-Deoxyuridine (BrdU) to cell DNA. Detection of BrdU-incorporated into the nucleus was accomplished by immunohistochemical procedure as previously described by Liu et al. ${ }^{22}$, using anti-BrdU as primary antibody. We also employed immunofluorescence to co-localize the BrdU with a neuronal marker, the neuronal pentraxin. This double staining was made in one rat of each group.

To immunohistochemistry and immunofluorescence procedures, $24 \mathrm{~h}$ after the SE onset all animals received 4 succeeding injections of BrdU (Sigma B-9285, 50 mg/kg body weight, i.p. dissolved in $0.07 \mathrm{~N} \mathrm{NaOH}, 0.9 \% \mathrm{NaCl}$ ) using an interval of $2 \mathrm{~h}$ between each injection since $\mathrm{BrdU}$ is available for uptake into cells synthesizing DNA for approximately 2 hours ${ }^{20}$. All animals were killed 1 day after the last BrdU injection since this period is sufficient to complete one cell cycle in S phase $\mathrm{e}^{21}$. The animals were deeply anaesthetized with halotane and the brains were rapidly removed and immersed in a fixative solution and processed with paraffin-embedded histological procedure. To DNA denaturation the slides were incubated in $50 \%$ formamide $/(0.3 \mathrm{M} \mathrm{Na}-$ $\mathrm{Cl}, 0.03 \mathrm{M} \mathrm{C}_{6} \mathrm{H}_{5} \mathrm{Na}_{3} \mathrm{O}_{7} .2 \mathrm{H}_{2} \mathrm{O}$ ) during $2 \mathrm{~h}$ at $65^{\circ} \mathrm{C}$, rinsed in $0.3 \mathrm{M}$ $\mathrm{NaCl}, 0.03 \mathrm{M} \mathrm{C}_{6} \mathrm{H}_{5} \mathrm{Na}_{3} \mathrm{O}_{7} .2 \mathrm{H}_{2} \mathrm{O}$, followed by $2 \mathrm{~N} \mathrm{HCl}$ for 30 min at $37{ }^{\circ} \mathrm{C}$ and by $0.1 \mathrm{M}$ boric acid for $10 \mathrm{~min}$, according to the method described by Liu et al. ${ }^{22}$. For detection of BrdU-labeled nuclei, slides were incubated in 1:50 anti-BrdU (Dako, Carpinteria, CA, USA) at 4. C overnight. Single-label immunohistochemistry in the sections was carried out by using specific secondary antibody and streptavidin-biotin complex solutions (Dako, Carpinteria, CA, USA, Strept AB Complex HRP-Duet, mouse/rabbit) and subsequently developed by using 3,3'-diaminobenzidine (DAB) $\left(0.25 \mathrm{mg} / \mathrm{mL}, 0.01 \% \mathrm{H}_{2} \mathrm{O}_{2}\right)$. After mounting, histological sections were dehydrated and cover-slipped with Entellan. Slides were observed using an optic microscopy Zeiss, Axiolab and representative images of the dentate gyrus $(0.67 \mathrm{~mm} \times 0.5 \mathrm{~mm})$ were digitized using NIH Image 1.61 system. The BrdU positive nuclei (round or oval medium-size) localized in the granule cells layer and in the supra granular zone (SPZ), were counted. Small BrdUpositive nuclei that appeared to be glial cells (less than $5 \mu \mathrm{m}$ in diameter) were excluded from the analysis. This procedure was identical to that described by Parent et al. ${ }^{4}$. The positive nuclei (Fig 1A) were counted in both hemispheres (three slides per animal) to obtain a mean for each rat and a mean \pm standard error for each group.

The number of proliferative cells from control and experimental animals of all groups was compared using paired Student t-test. This test was employed due to its abilities to raise critical variations between control and experimental animals, eliminating from the statistical evaluation the irrelevant variations between pairs due to nutritional, maternal or genetic factors. Values from experimental animals of different groups, were 


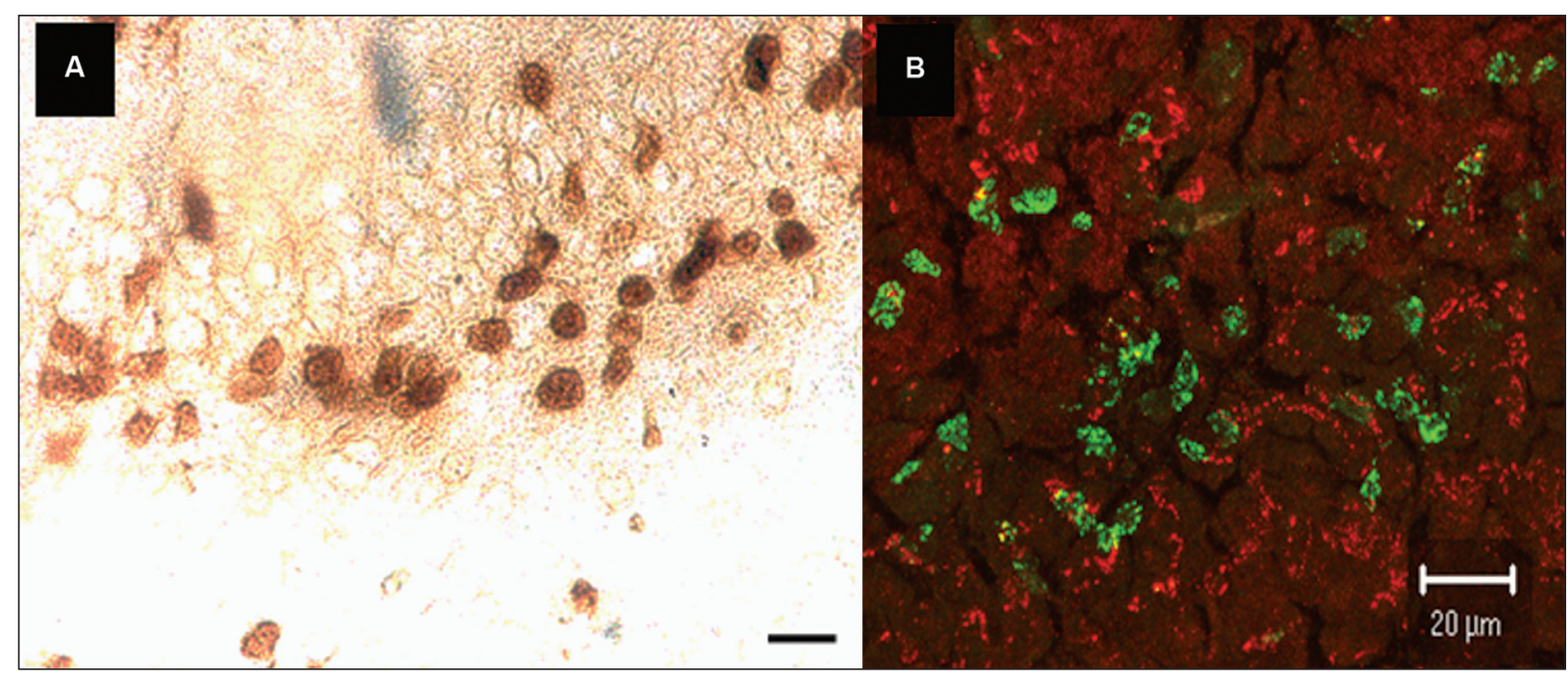

Fig 1. Immunostaing in the dentate gyrus. (A) BrdU positive cells in the dentate gyrus detected by immunohistochemistry. (B) Immunofluorescence showing double labeling of BrdU proliferative cells, in green associated to a neuron marker (Neuronal Pentraxin), in red. Scale Bar=20 $\mu$ m.

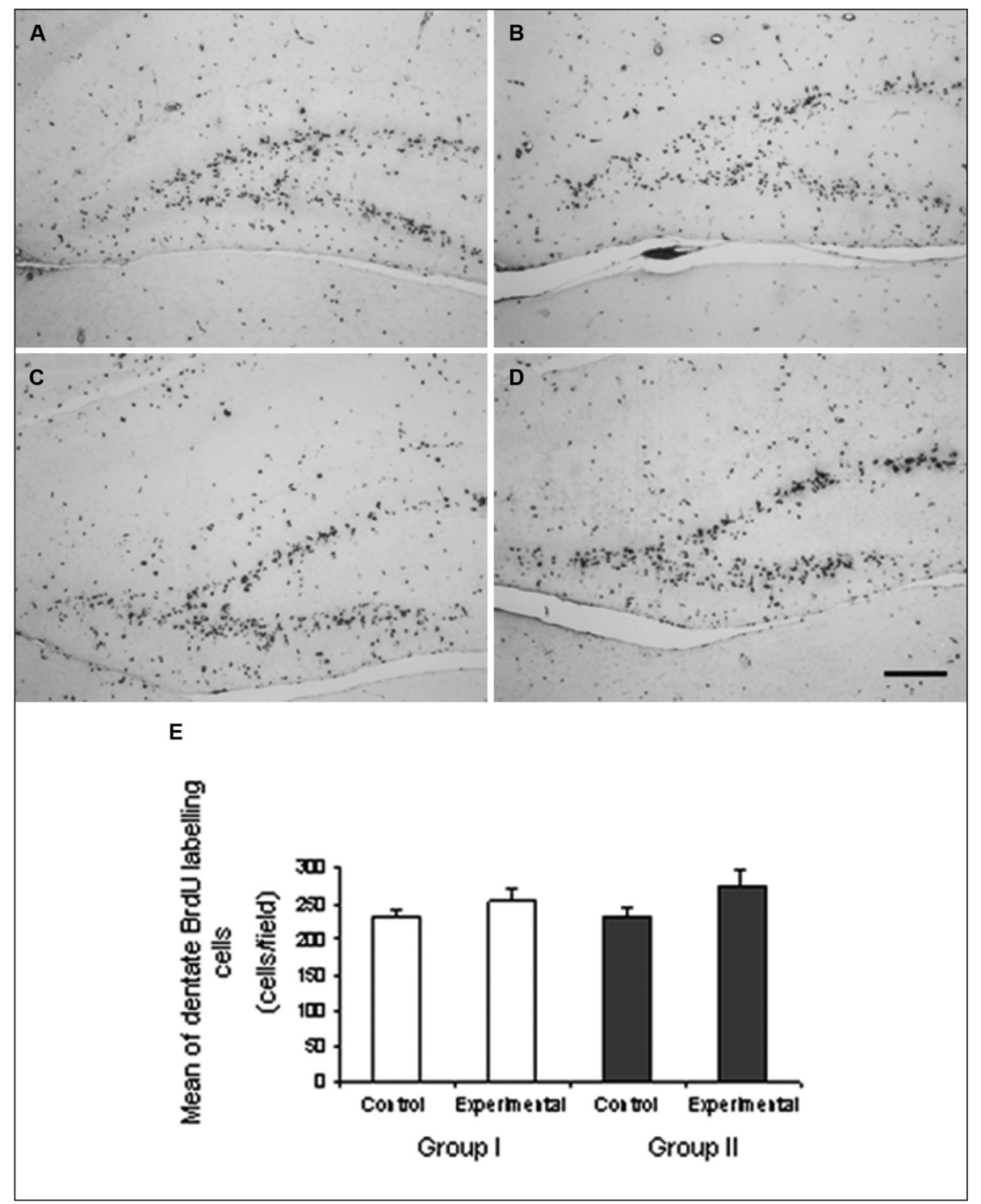

Fig 2. BrdU immunostaining in the dentate gyrus of animals from the groups I and II. (A) Group I (P9-control), (B) Group I (P9-experimental), (C) Group II (P7,8,9-control), (D) Group II (P7,8,9experimental), (E) BrdU positive cells quantification of the Groups I (P9) and II (P7,8,9). Scale bar $=200 \mu \mathrm{m}$. 




Fig 3. BrdU immunostaining in the dentate gyrus of animals from the groups III and IV. (A) Group III (P17-control), (B) Group III (P17-experimental), (C) Group IV (P21-control), (D) Group IV (P21-experimental), (E) BrdU positive cells quantification of the Groups III (P17) and IV (P21). * $p<0.05$ (Student $t$ test). Scale bar=130 $\mu \mathrm{m}$.

compared used unpaired Student $t$ test $(p \leq 0.05$ was accepted as significant) using SSPS software.

To double staining (immunofluorescence) one animal per group was deeply anaesthetized with halotane and the brain was rapidly removed and immersed in $2 \%$ paraformaldehyde for 30 minutes and the tissue was stored at $-200^{\circ} \mathrm{C}$. The slices were cut, mounted and post-fixed in paraformaldehyde for $30 \mathrm{~min}$. The DNA denaturation was developed as previously described. The immunofluorescence was carried out using anti-BrdU (1:50) and anti-neuronal pentraxin (1:50) (Transduction Laboratories Lexington, KY, USA) and the secondary antibodies used were conjugated with Alexa fluor 488 (green) and Alexa fluor 594 (red) (Molecular Probes, Eugene, OR, USA). Neuronal Pentraxin is a protein exclusively expressed by neurons and it is related to synapse remodeling ${ }^{23}$. The slides were visualized using confocal microscopy and the co-localization was documented (Fig 1B).

In another type of experiment, three randomly selected animals per group were assigned to individual acrylic transparent 

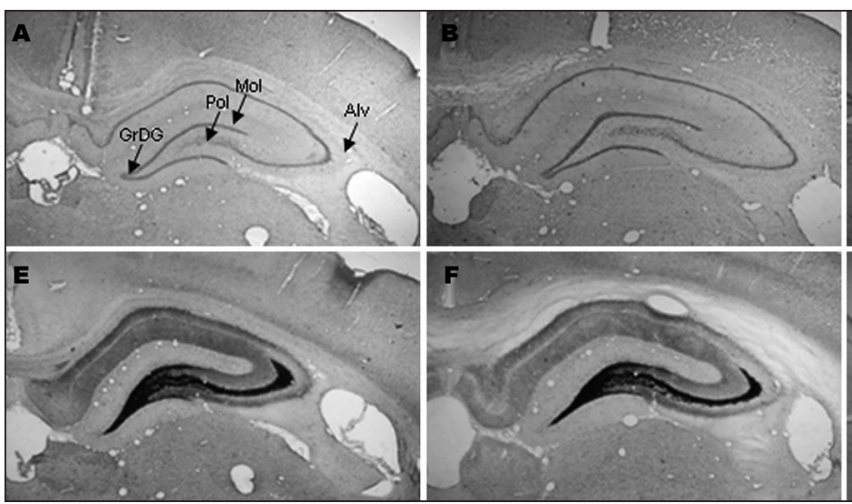

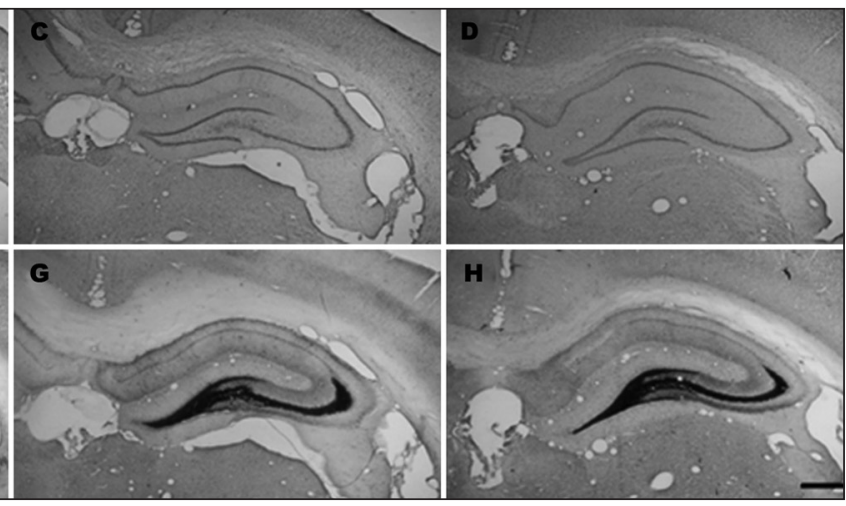

Fig 4. The hippocampal cytoarchitecture, visualized using Nissl staining (A to D) and the hippocampal mossy fibers, visualized by Neo-Timm technique (E to H), during adult life. (A and E) Group I (P9-control), (B and F) Group I (P9-experimental), (C and G) Group II (P7,8,9-control), $(D$ and $H)$ Group II (P7,8,9-experimental). Scale bar $600 \mu \mathrm{m}$. The arrows indicate: GrDG=granular layer dentate gyrus; Pol=polymorphic layer; Mol=molecular layer; Alv=Alveus.

cages after the wean and were video-monitored (Stellate, inc. video-tape system) during 8 hours/day $(7 \mathrm{am} / 7 \mathrm{pm}$ light/dark cycle) until P120 in order to detect the appearance of spontaneous seizures, during later periods. After the video-monitoring period, the brains of these animals were processed to NeoTimm and Nissl staining. For this purpose P120 rats were deeply anaesthetized (pentobarbital $50 \mathrm{mg} / \mathrm{kg}$ body weight) and the perfusion, through fixed aorta, were made with $25 \mathrm{~mL}$ of Millonigs's buffer (MB), $50 \mathrm{~mL}$ of $0.1 \%$ sodium sulfide ( $\mathrm{Na}_{2} \mathrm{~S}$ solution) diluted in $\mathrm{MB}, 100 \mathrm{~mL}$ of $3 \%$ glutaraldehyde $\mathrm{pH} 7.4$ and $200 \mathrm{~mL}$ of $0.1 \%$ sodium sulfide, diluted in $\mathrm{MB}$. The brains were carefully dissected and transferred to $30 \%$ sucrose solution diluted in glutaraldehyde overnight, for post-fixation. Brains were cut in 40 $\mu \mathrm{m}$-thick (coronal sections) and disposed in phosphate buffer. Representative sections were mounted in glass slides and dried before staining procedure. The Neo-Timm method was developed according to Babb et al.". Nissl staining $(0.5 \%$ cresyl violet in $0.3 \%$ acetic acid) was also performed in some sections. Slidemounted sections were dehydrated, mounted and cover-slipped for histological examination using optic microscope. Timm analysis was made based in the scale described by Holmes et al. ${ }^{24}$.

\section{RESULTS}

The SE onset, presented by animals from groups I and II were very similar. The ictal period started less then 10 minutes after pilocarpine injection, lasting for 2 hours. The rats showed body tremor, mastication jaw movements, and head turning from side to side, cloning movements of forelimbs, episodes of running and loss of posture culminating in SE. Some tonic seizures were observed in both groups, which were accompanied by urinary and fecal incontinence. After seizures animals stayed quiet but hyper-responsive to stimulus, preferring isolation and no feeding for 4 to 6 hours. The mortality due to SE in the groups I and II was null ( $0 \%$ of mortality)

Pilocarpine induced seizures in group III started ap- proximately 15 minutes after pilocarpine administration, when mastication movements were observed followed by body tremor and jumps, running, posture loss and lateral fall. Increased salivation and cloning movements with forelimbs were frequently observed. Tonic seizures with oral cyanosis were observed in all animals. The ictal period lasted about 5 hours and the animals returned to the baseline behavior within 24 hours. The mortality during this period was $16.6 \%$.

The rats from groups I, II and III did not exhibit spontaneous seizures during the period of video-tape recording.

In animals of P21 (group IV), the seizures started between 30 minutes and 1 hour after pilocarpine administration. The behavior change consisted of mastication movements followed by scratching their muzzles, salivation, stops on hindlimbs accompanied by cloning movements of forelimbs. Severe tonic seizures, inducing death, were observed (69\% of mortality) and the SE period lasted 6-8 h. The animals remained hyper-responsive during 24 hours following pilocarpine injection. Video-tape recordings showed that these animals presented spontaneous recurrent seizures, during the adult life, as previously described ${ }^{17}$.

The immunofluorescence assay showed that some BrdU positive cells were co-localized with the neuronal pentraxin (Fig 1B).

The dentate gyrus of the animals processed for BrdU immunohistochemistry, 24 hours after the last BrdU injection, revealed BrdU-labeled cells throughout the dentate gyrus. Many of the BrdU-labeled cells had the morphological characteristics of granule cells precursors, i.e., round or oval, medium-sized cell bodies, sometime observed as clusters of cells. The quantification of proliferative cells showed no difference in the intensity of cellular proliferation in rats submitted to one SE at P9 (254 \pm 17.77$)$ (cells/ field), when compared to its control group (233.5 \pm 7.88$)$. 

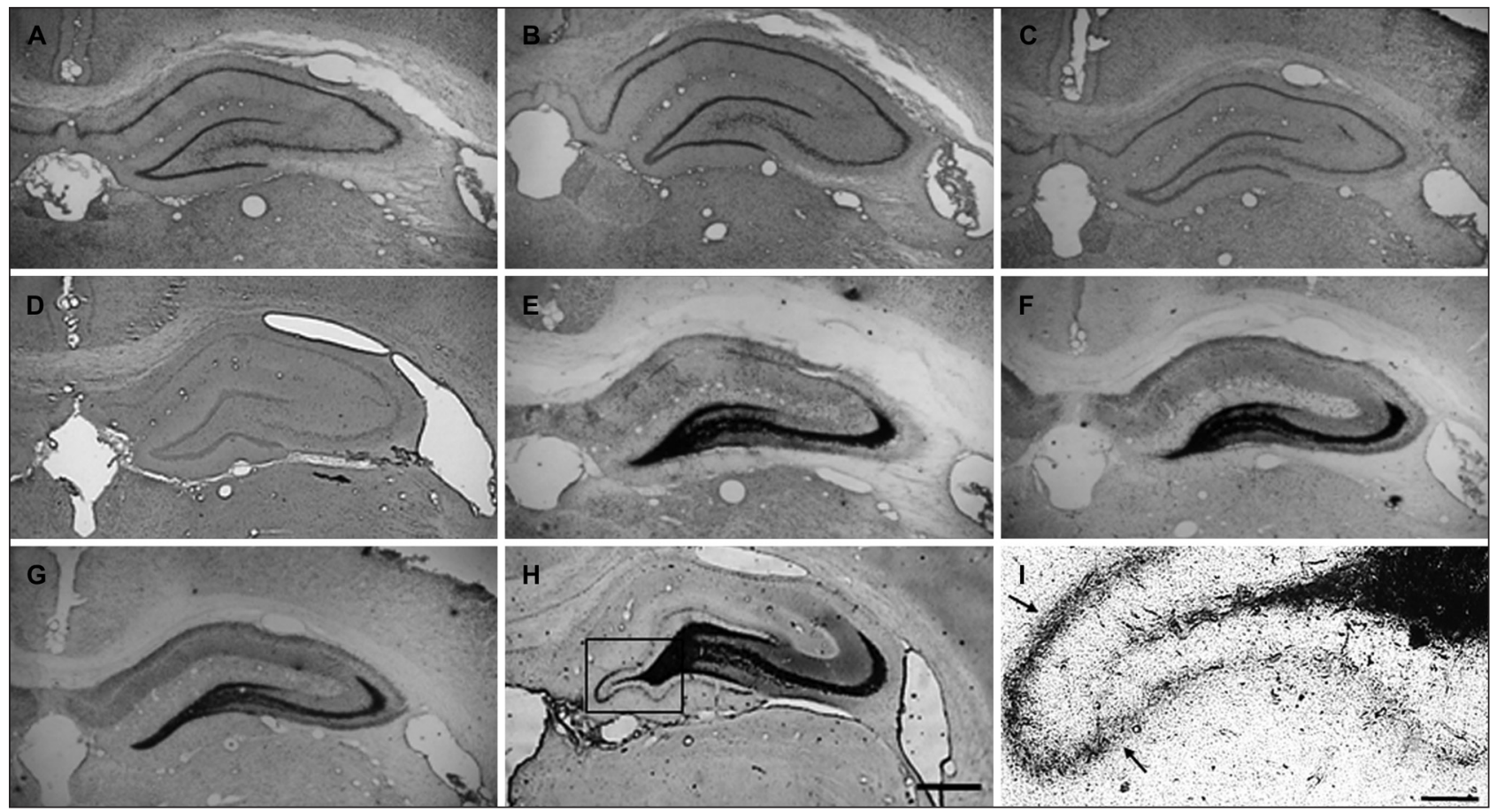

Fig 5. The hippocampal cytoarchitecture, visualized using Nissl staining ( $A$ to $D)$ and the hippocampal mossy fibers, visualized by Neo-Timm technique (E to I), during the animals adult life. (A and E) Group III (P17-control), (B and F) Group III (P17-experimental), (C and G) Group IV (P21control), (D and H) Group IV (P21-experimental), (I) Magnification of square observed in H. Notice the presence of mossy fibers sprouting (arrows). Scale bars. $A$ to $G=600 \mu \mathrm{m}$ and $I=100 \mu \mathrm{m}$.

Furthermore, no differences were also observed when rats submitted to three episodes of SE (274.6 \pm 22.33$)$ were compared to its control group (231.2 \pm 12.69$)$. When the number of BrdU-stained cells was compared in experimental animals from groups I and II no difference was found too (Fig 2). This finding suggests that single or multiple episodes of SE did not modify the normal rate of the dentate gyrus cell proliferation in animals of these ages. The comparison between both control groups (I and II) also revealed no significant difference in cell proliferation, suggesting that experimental manipulations (injection procedures) did not by itself alter this process at these age.

The analysis of hippocampal proliferative neurons in older animals (group III) showed that animals submitted to $\mathrm{SE}$ at P17 present increased neurogenesis $(83.6 \pm 6.63)$, when compared to its control group $(67.3 \pm 5.15)(p=0.007)$ (Figs 3A,3B,3E).

P21 rats, submitted to SE also showed an increase of BrdU-positive cells in the dentate gyrus (117.5 \pm 12.15$)$ when compared to its control group (61.3 \pm 5.58$)(p=0.006)$ (Figs $3 C, 3 D, 3 E)$. The comparison between experimental animals of groups III and IV demonstrated that the number of proliferative cells was significantly higher in animals experiencing SE at P21 age ( $p=0.049)$.

Animals from groups I,II and III presented grade zero of mossy fibers sprouting in the dentate gyrus (Figs 4E,4H and Figs 5E,5F). The animals suffering SE at P21 (group IV) showed Timm staining in the supragranular layer of the dentate gyrus, consisting with an aberrant synaptic reorganization and sprouting, grade II/V (Figs 5G,5I). Evident alterations, visualized by Nissl staining of hippocampal architecture, were not found in all groups (Figs 4A,4D and Figs 5A,5D).

\section{DISCUSSION}

The hippocampus is an important structure related to memory and learning. It is involved in several central nervous system (CNS) pathologies such as in epilepsy. Postnatal neurogenesis phenomenon has been observed in the hippocampus of several species ${ }^{2,25}$ including in humans, where an incorporation of $\mathrm{BrdU}$ was found in neurons, after the death of patients, previously treated with this drug', but the mechanisms regulating postnatal neurogenesis are not completely clear.

The present study shows two important findings concerning to neurogenesis increment, induced by long-lasting seizures. The neuronal proliferation is age-dependent in the dentate gyrus, and young rats (P9 and P7) submitted to one or three episodes of SE, respectively, did not show modification in the number of BrdU-stained cells into the hippocampal formation. Only pilocarpine-induced SE at P17 and P21 (long-lasting SE when compared with the SE at $\mathrm{P} 9$ or P7) was able to increase the number of proliferative 
cells in the dentate gyrus. The present work also suggests a disconnection between two important events, the hippocampal mossy fiber sprouting and the amplification of neurogenesis process after long-lasting SE.

One or three SE insults during the second week of a rat's life (P9) did not modify the number of dividing cell in the SGZ region, supporting the idea that the intensity of insult (number of SE) is not significantly relevant to trigger such phenomenon, in young animals. As in adult life these animals present impairment of learning and memory ${ }^{19}$ other pathways could be altered in the brain during long-lasting SE, but the increase of neurogenesis is not involved. Neither the neurogenesis is related to absence seizures, presented by some of these animals during the adult life.

The developing of rat brain completes its formation after birth but in the first days of life, the rate of cell in division is very high. Consequently, a large number of young cells migrate to their final destination but, only those that obtain integration into the active neural circuits have the possibility to survive. In fact, recent findings suggest that newly emerging cells could die by several mechanisms including apoptosis ${ }^{26}$. Thus, the cell division is a process highly controlled in the developing brain and an important set of molecules are involved in its control ${ }^{27}$. For this reason we suggest that immature brain requires intense strategies to maintain the long-term proliferative capacity as well as the undifferentiated state of dentate precursor cells, for future events. Thus, severe insults such as one or three episodes of SE, or painful manipulations (i.p. injections) generated in young rats (during the second week of life) were not able to modify the refined control of neurogenesis in immature brain.

On the other hand, epileptic insults trigger the development of abnormal pathways in young brain and incorrect or abnormal synaptic connections could determine future dysfunction. Santos et al. ${ }^{19}$ observed learning and memory impairment in adult rats submitted to SE at P9. In agreement, a profound impairment of cognition associated to no cell loss were also observed by de Rogalski et al. ${ }^{28}$, in animals submitted to chemical kindling induced by flurothyl, during the first 12 days of life ( 55 seizures). In contrast, McCabe et al. ${ }^{29}$, reported a decreased neurogenesis in the dentate gyrus of young animals (PO and P4) followed the $25^{\text {th }}$ flurothyl-induced seizure. Indeed, the brain response is always dependent of the nature and intensity of stimulus and each stage of rat development could be unique. Hours or days could open or close windows, which will determine the response of an immature brain, submitted to different type of stimulus.

According with previous findings ${ }^{17,19}$, the Timm staining showed that mossy fiber sprouting was present in the hip- pocampus of animals from P21 but not in younger animals, allowing us to suggest that there is no direct relationship between increased hippocampal neurogenesis and the reorganization of the mossy fiber, in the dentate gyrus. Thus, our data are in agreement with previous results of Parent et al. $^{30}$ and Covolan et al. ${ }^{9}$ since they previously suggested that mossy fiber sprouting and neurogenesis of granule cells are not necessarily linked phenomena in adult animals. In addition, the present data suggest that neurogenesis is not related to mossy fiber sprouting neither is related to the appearance of spontaneous limbic seizures.

ACKNOWLEDGMENT - We thank Hilda da Silva Reis for her excellent technical assistance.

\section{REFERENCES}

1. Eriksson PS, Perfilieva E, Björk-Eriksson T, et al. Neurogenesis in the adult human hippocampus. Nat Med 1998;4:1313-1317.

2. Kornack DR, Rakic P. Continuation of neurogenesis in the hippocampus of the adult macaque monkey. Proc Natl Acad Sci 1999;96:5768-5773.

3. Cameron HA, McKay RD. Adult neurogenesis produces a large pool of new granule cells in the gyrus. J Comp Neurol 2001;435:406-417.

4. Parent J, Yu T, Leibowitz R, Geschwind D, Sloviter R, Lowenstein D. Dentate granule cell neurogenesis is increased by seizures and contributes to aberrant network reorganization in the adult rat hippocampus. J Neurosci 1997;7:3727-3738.

5. Gould E, McEwen BS. Adrenal hormones suppress cell division in the adult rat dentate gyrus. J Neurosci 1992;12:3642-3650.

6. Åberg MAI, Åberg ND, Hedbäcker H, Oscarsson J, Eriksson OS. Peripheral infusion of IGF-I selectively induces neurogenesis in the adult rat hippocampus. J Neurosci 2000;20:2896-2903.

7. van Praag H, Christie BR, Sejnowski T, Gage FH. Running enhances neurogenesis, learning, and long-term potentiation in mice. PNAS 1999;96:13427-13431.

8. Madsen TM, Treschow A, Bengzon J, Bolwig TG, Lindvall O, Tingström A. Increased neurogenesis in a model of electroconvulsive therapy. Biol Psych 2000;47:1043-1049.

9. Covolan L, Ribeiro LTC, Longo BM, Mello LEAM. Cell damage and neurogenesis in the dentate granule cell layer of adult rats after pilocarpineor kainate-induced status epilepticus. Hippocampus 2000;10:169-180.

10. Scott BW, Wang S, Burnham WM, De Boni U, Wojtowics JM. Kindlinginduced neurogenesis in the dentate gyrus of the rat. Neurosci Lett 1998;284:73-76.

11. Babb TL, Kupfer WR, Pretorius JK, Crandall PH, Levesque MF. Synaptic reorganization by mossy fibers in human epileptic fascia dentata. Neuroscience 1991;42:351-363.

12. Longo BM, Mello LEAM. Blockade of pilocarpine- or kainate-induced mossy fiber sprouting by cicloheximide does not prevent subsequent epileptogenesis in rats. Neurosci Lett 1997;226:163-166.

13. Tauck DL, Nadler JV. Evidence of functional mossy fiber sprouting in hippocamapal formation of kainic acid-treated rats. J Neurosci 5: 1016-1022.

14. Holmes GL, Gairsa JL, Chevassus ALN, Ben-Ari Y. Consequences of neonatal seizures in the rat: morphological and behavioral effects. Ann Neurol 1998;44:845-857.

15. Leite JP, Babb TL, Pretorius JK, Kuhlman PA, Yeoman KM, Mathern GW. Neuron loss, mossy fiber sprouting, and interictal spikes after intrahippocampal kainate in developing rats. Epilepsy Res 1996;26:219-231.

16. Wasterlain CG. Effects of neonatal status epilepticus on rat brain development. Neurology 1976;26:975-986.

17. Priel MR, Santos NF, Cavalheiro EA. Developmental aspects of the pilocarpine model of epilepsy. Epilepsy Res 1996;26:115-121.

18. Cavalheiro EA, Leite JP, Bortolotto ZA, Turski WA, Ikonomidou C, Turski L. Long term effects of pilocarpine in rats: structural damage of the brain triggers kindling and spontaneous recurrent seizures. Epilepsia 1991;32:778-782. 
19. Santos NF, Arida RM, Trinidade EM Filho, Priel MR, Cavalheiro EA. Epileptogenesis in immature rats following recurrent status epilepticus. Brain Res Rev 2000;32:269-276.

20. Packard DS, Menzies RA, Skalko RG. Incorporation of thymidine and its analog, bromodeoxyuridine, into embryos and maternal tissues of the mouse. Differentiation 1973;1:397-405

21. Nowakowski RS, Lewin SB, Miller MW. Bromodeoxyuridine immunohistochemical determination of the lengths of the cell cycle and the DNA-synthetic phase for an anatomically defined population. J Neurocytol 1989;18:311-318.

22. Liu J, Solway K, Messing RO, Sharp FR. Increased neurogenesis in the dentate gyrus after transient global ischemia in gerbils. J Neurosci 1998;18:7768-7778.

23. Omeis IA, Yung-Chin H, Perin MS. Mouse and human neuronal pentraxin 1 (NPTX1): Conservation, genomic structure, and chromosomal localization. Genomics 1996;36:543-545.

24. Holmes GL, Sarkisian M, Ben-Ari Y, Chevassus ALN. Mossy fiber sprouting after recurrent seizures during early development in rats. J Comp Neurol 1999;404:537-553.
25. Richards LJ, Kilpatric TJ, Bartlett PF. De novo generation of neuronal cells from the adult mouse brain. Proc Natl Acad Sci 1992;89: 8591-8595.

26. Biebl M, Cooper CM, Winkler J, Kuhn HG. Analysis of neurogenesis and programmed cell death reveals a self-renewing capacity in the adult rat brain. Neurosci Lett 2000;291:17-20.

27. Pleasure SJ, Collins AE, Lowenstein DH. Unique expression pattern of cell fate molecules delineate sequential stages of dentate gyrus development. J Neurosci 2000;5:6095-6105.

28. Rogalski LI, Minokoshi M, Silveira D, Ho Cha B, Holmes GL. Recurrent neonatal seizures: relationship of pathology to the electroencephalogram and cognition. Dev Brain Res 2001;129:27-38.

29. McCabe BK, Silveira DC, Cilio MR. Reduced neurogenesis after seizures. J Neurosci 2001;21:2094-2103.

30. Parent JM, Tada E, Fike JR, Lowenstein DH. Inhibition of dentate granule cell neurogenesis with brain irradiation does not prevent seizureinduces mossy fiber synaptic reorganization in the rat. J Neurosci 1999;19:4508-4519. 